Agr. Biol. Chem., 38 (6), 1203 1208, 1974

\title{
Large Scale Production of Erythritol and Its Conversion to D-Mannitol Production by $n$-Alkane-grown Candida zeylanoides
}

\author{
Kiyoji HatTori and Takeo Suzuki \\ Tokyo Research Laboratory, Kyowa Hakko Kogyo Co., Ltd, Machida, Tokyo \\ Received December 28, 1973
}

\begin{abstract}
Production of erythritol by $n$-alkane-grown Candida zeylanoides KY 6166 was studied using large scale fermentors under conditions described in the previous report. The medium$\mathrm{pH}$ was kept below 4.0 during fermentation in 5-liter or 300-liter fermentors. This strain produced about $180 \mathrm{mg} / \mathrm{ml}$ of meso-erythritol and a small amount of mannitol. The yield corresponded to $90 \%$ of $n$-alkane consumed.

The production ratio between erythritol and mannitol was affected remarkably by the concentration of phosphate in the medium. Keeping its concentration at high level (0.04 to $0.20 \mathrm{mg} / \mathrm{ml}$ as $\mathrm{KH}_{2} \mathrm{PO}_{4}$ ), erythritol production was almost entirely converted to mannitol production. The yield was $63 \mathrm{mg} / \mathrm{ml}$ after $100 \mathrm{hr}$ incubation in 5-liter fermentor, which corresponded to $52 \%$ of $n$-alkane consumed. Conversion of the production of erythritol to mannitol was also observed in several other yeasts capable of utilizing $n$-alkane as the sole source of carbon.
\end{abstract}

In the previous paper, ${ }^{1)}$ we reported that meso-erythritol was produced in a yield of $55 \%$ on $n$-alkane consumed when Candida zeylanoides was incubated at a $\mathrm{pH}$ range from 2.5 to 4.0 in the Erlenmeyer flask. Tabuchi and Hara $^{23}$ demonstrated that D-mannitol was predominantly produced by Candida lipolytica when grown in $n$-alkane medium without controlling the medium-pH. In both reports, however, there was no explanation for the reason why such a difference in the predominant product occurred between these microorganisms.

During the course of further study on erythritol fermentation in large scale fermentors, we found that another polyol was predominantly produced depending on the culture conditions. This polyol was partially characterized as D-mannitol. The present investigation was undertaken to examine the relationship between the production of erythritol and mannitol.

This paper is concerned with the isolation and identification of the mannitol-like substance. A procedure for large scale production of erythritol and a possible factor responsible for the conversion in the fermentation of erythritol to mannitol are also described.

\section{MATERIALS AND METHODS}

Microorganisms. Candida zeylanoides KY 6166, a glycerol auxotroph mutant, was employed throughout this study. Other strains were also employed partly to compare with the above organism. All the strains were kindly supplied by Mr. Takayama et al. of this laboratory.

Media and culture conditions. The composition of the medium for cultivation of yeasts was as follows: $n$-paraffin (C-12 to C-15), 10 to $20 \%$ (w/v); $\mathrm{KH}_{2} \mathrm{PO}_{4}$, $0.03 \%$; $\mathrm{MgSO}_{4} \cdot 7 \mathrm{aq}, 0.05 \%$; ammonium sulfate, $0.5 \%$; glycerol, $0.05 \%$; thiamine- $\mathrm{HCl}, 1 \mathrm{mg} / \mathrm{liter} ; \mathrm{MnSO}_{4}$. $5 \mathrm{aq}, 2 \mathrm{mg} / \mathrm{liter} ; \mathrm{ZnSO}_{4} \cdot 7 \mathrm{aq}, 2 \mathrm{mg} / \mathrm{liter}$; $\mathrm{CuSO}_{4} \cdot 5 \mathrm{aq}$, $50 \mu \mathrm{g} /$ liter; in tap water. The $\mathrm{pH}$ was adjusted to 5.0 before sterilizing. The yeast was grown in a 5-liter fermentor containing 3 liters of the culture medium on an agitation cycle of $600 \mathrm{rpm}$ and aeration of 3 liters per minute at $30^{\circ} \mathrm{C}$. In each run, inoculum $(300 \mathrm{ml})$ was preincubated in the seed medium for $30 \mathrm{hr}$ at $30^{\circ} \mathrm{C}$ on a rotary shaker $(220 \mathrm{rpm})$, which was composed of $n$-paraffin (C-12 to C-15), $5 \%(\mathrm{w} / \mathrm{v}) ; \mathrm{KH}_{2} \mathrm{PO}_{4}, 0.1 \%$; $\mathrm{MgSO}_{4} \cdot 7 \mathrm{aq}, 0.05 \%$; ammonium sulfate, $0.5 \%$; glycerol $0.01 \% ; \mathrm{MnSO}_{4} .7 \mathrm{aq}, 2 \mathrm{mg} / \mathrm{liter} ; \mathrm{ZnSO}_{4} \cdot 7 \mathrm{aq}, 2 \mathrm{mg} /$ liter; $\mathrm{FeSO}_{4} \cdot 7 \mathrm{aq}, 1 \mathrm{mg} / \mathrm{liter}$; $\mathrm{CuSO}_{4} \cdot 5 \mathrm{aq}, 50 \mu \mathrm{g} / \mathrm{liter}$; thiamine-HCl, $1 \mathrm{mg} / \mathrm{liter}$; and tap water. During the fermentation, the medium-pH was automatically controlled at 3.5 with $28 \%$ ammonia water.

Analytical methods. Cell growth was determined by 
methods previously described. ${ }^{11}$ Citric acid was analyzed by the same method as described by Nakanishi et al. ${ }^{3)}$ Polyol was also assayed with the aqueous phase obtained by centrifugation of the broth culture by the method described in the previous paper. ${ }^{11}$

Chemicals. n-Alkane containing $\mathrm{C}-12$ to $\mathrm{C}-15$ fractions was obtained from Nikko Petrochemical Co. (Japan). meso-Erythritol and D-mannitol were obtained from Tokyo Kasei Chemical Co. All other chemicals were the best reagent grades available.

\section{RESULTS AND DISCUSSION}

Production of polyols in large scale fermentors

The previous paper ${ }^{1}$ showed that the citric acid-producing yeast, Candida zeylanoides KY 6166, produced a considerable amount of meso-erythritol from $n$-alkane only when the medium-pH was kept constantly at low levels (2.5 to 4.0 ) in 300-ml Erlenmeyer flasks. The effect of the medium-pH on erythritol production was examined in more detail using 5-liter fermentor equipped with an automatic $\mathrm{pH}$ controller. As shown in Table I, citric acid

Table I. Effect of Medium-pH on Polyol Production BY Candida zeylanoides KY 6166

Incubation of strain KY 6166 was carried out with $10 \%(\mathrm{w} / \mathrm{v})$ of $n$-alkane for $100 \mathrm{hr}$ in 5-liter fermentor as described under MATERIALS AND METHODS. Hexitol was estimated as mannitol.

\begin{tabular}{ccccc}
\hline pH & $\begin{array}{c}\text { Growth } \\
\text { (O.D.) }\end{array}$ & $\begin{array}{c}\text { Erythritol } \\
\text { produced } \\
(\mathrm{mg} / \mathrm{ml})\end{array}$ & $\begin{array}{c}\text { Hexitol } \\
\text { produced } \\
(\mathrm{mg} / \mathrm{ml})\end{array}$ & $\begin{array}{c}\text { Citric acid } \\
\text { produced } \\
(\mathrm{mg} / \mathrm{ml})\end{array}$ \\
\hline 6.5 & 0.725 & 0 & 0 & 84 \\
5.5 & 0.640 & 0 & 0 & 87 \\
4.5 & 0.650 & 12 & 3.2 & 53 \\
4.0 & 0.530 & 59 & 5.6 & 16.8 \\
3.5 & 0.510 & 73 & 7.1 & 13.2 \\
3.0 & 0.490 & 75 & 7.2 & 10.8 \\
\hline
\end{tabular}

production was remarkably depressed in the incubation at low $\mathrm{pH}$ (3.0 to 4.0), while erythritol production increased remarkably below $\mathrm{pH} 4.0$. In order to provide further evidence for the critical effect of medium-pH on polyol fermentation, time course of production after the shifting-up or-down of $\mathrm{pH}$ was carefully examined during the production phase of fermentation. As shown in Fig. 1,

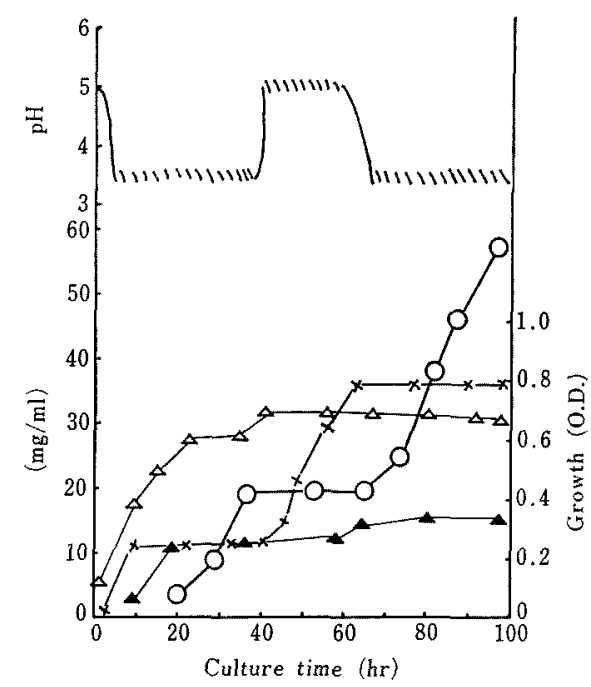

FIG. 1. Effect of Medium-pH on Polyol Production in 5 liter Fermentor by Candida zeylanoides KY 6166. Incubation was carried as described under the MATERIALS AND METHODS, in which the medium-pH was varied as shown in the figure.

$\triangle$, Cell growth; $O$, erythritol; $\boldsymbol{\Lambda}$, hexitol (as mannitol); $x$, citric acid (as free acid).

shifting-up to 5.0 from 3.5 resulted immediately in lowering the production rate of erythritol, accompanied by an increase in the rate of citric acid production. In contrast, an increase in the rate of erythritol production and a lowering of citric acid production was observed immediately after $\mathrm{pH}$ was adjusted to 3.5 . Cell growth was depressed by lower $\mathrm{pH}$. The above results suggested that the key enzyme responsible for citric acid biosynthesis was inactivated by low-pH and the shunt of erythritol synthesis was consequently stimulated. Subsequently, the fermentation was studied again by controlling the medium-pH at the range from 3.5 to 4.0 throughout the operation. The result is shown in Fig. 2, in which approximately $180 \mathrm{~g} /$ liter of erythritol was produced at the expense of $200 \mathrm{~g} /$ liter of $n$-alkane. Similar yields were also obtained in another experiment with 300 -liter fermentors.

During the course of this study, another polyol was apparently detected as a minor product, whose $R f$ corresponded to that of mannitol as shown in the previous paper." Thus, an attempt was made to study the cor- 


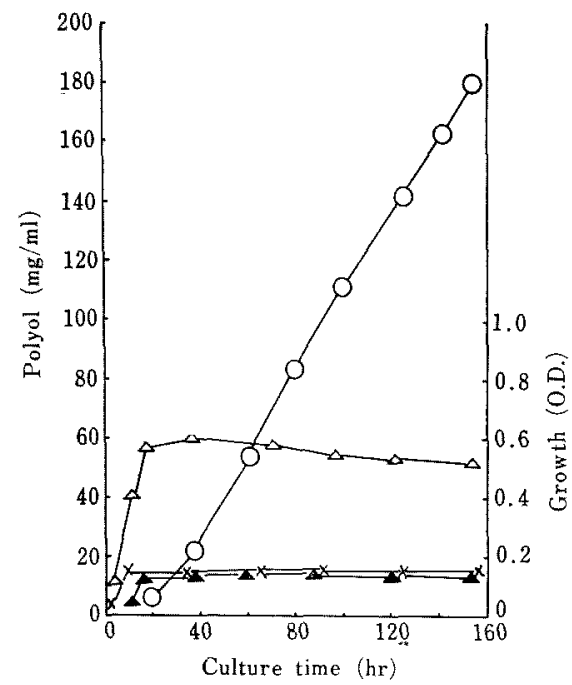

FIG. 2. Time Course of Erythritol Production in 5 liter Fermentor by Candida zeylanoides KY 6166 .

Incubation was carried out with $20 \%$ of $n$-alkane in the medium described under MATERIALS AND METHODS.

$\triangle$, Cell growth; $O$, erythritol; $\boldsymbol{\Lambda}$, hexitol (as mannitol); $x$, citric acid (as free acid).

relation between production of mannitol and erythritol in more detail, because no explanation was given for the difference between our results and the findings of Tabuchi and Hara in the production of mannitol by Candida lipolytica. ${ }^{2)}$ Prior to starting the study, the isolation of the mannitol-like substance was undertaken to identify it more accurately.

Isolation and identification of mannitol-like substance

After incubation of Candida zeylanoides KY 6166 in 5-liter fermentor for $120 \mathrm{hr}$. A portion (1.0 liter) of the supernatant obtained by centrifugation of the culture broth ( $\mathrm{pH} 3.5$ ) was passed through a $50 \mathrm{~cm}^{2} \times 40 \mathrm{~cm}$ column of anion exchange resin (Diaion $\mathrm{SK}-1 \mathrm{H}^{+}$ form) to remove cationic materials. The effluent ( $\mathrm{pH}$ 1.5) was then passed through a $50 \mathrm{~cm}^{2} \times 20 \mathrm{~cm}$ column of anion exchange resin (Diaion SA-1B $\mathrm{OH}^{-}$form). The yield of polyol recovered by these processes was $75 \%$ of the initial amount. The effluent ( $\mathrm{pH} 5.5$, 2.5 liters) was concentrated to approximately $150 \mathrm{ml}$ at $40^{\circ} \mathrm{C}$ in vacuo. The concentrate gave two spots in paper chromatography. The separation of these polyols was carried out by chromatography on a $6.8 \mathrm{~cm}^{2} \times 35 \mathrm{~cm}$ column of anion exchange resin (Diaion SA-1B Borate form) using the previous method." Mannitol-like substance was eluted separately from erythritol with the $0.05 \mathrm{M}$ borax solution ( 0.8 liters). The fraction was treated with cation exchange resin (Diaion $\mathrm{SK}-1 \mathrm{H}^{+}$form) to remove sodium ion, and then concentrated to syrup at $50^{\circ} \mathrm{C}$. Boric acid was removed with methanol under reduced pressure. The syrup was subsequently dissolved in a small volume of hot ethanol and filtrated. The filtrate was left standing in a cold room overnight. White crystals appeared; they were collected and were recrystallized repeatedly with ethanol and dried at $60^{\circ} \mathrm{C}$ in vacuo overnight. Six grams of dried material were obtained. The material thus isolated was ascertained to give a single spot by paper chromatography and was identical with the compound observed initially in the culture broth. The isolated crystals were freely soluble in water and in warm ethanol. The melting point was 166 to $168^{\circ} \mathrm{C}$ (uncorrected) and no depression was observed by mixing with authentic D-mannitol. Chromatographic behaviour was completely the same as that of D-mannitol. Optical rotation, $[\alpha]_{\mathrm{D}}^{25}=+24.3 \quad(c=7.8$ in saturated borax solution), was also consistent with that of D-mannitol. Furthermore, infrared analysis demonstrated a good agreement between the spectra of authentic D-mannitol and isolated polyol. These findings led to the conclusion that the substance isolated as byproduct in erythritol fermentation was Dmannitol.

Conversion of erythritol fermentation to mannitol fermentation by Candida zeylanoides KY 6166

The previous paper ${ }^{1 !}$ indicated that the addition of a natural nutrient such as meat extract or yeast extract into the medium designed for erythritol fermentation led to a significant increase in the production ratio of $\mathrm{D}$-mannitol to erythritol. Tabuchi and $\mathrm{Hara}^{2)}$ reported 
Table II. Effect of Natural Nutrients on Polyol Production BY Candida zeylanoides KY 6166

Incubation of strain KY 6166 was carried out as described under the MATERIALS AND METHODS, in which ammonium sulfate was replaced by each nitrogen source shown in the table. Hexitol was presented as mannitol.

\begin{tabular}{lcccrc}
\hline Nitrogen source & $\begin{array}{c}\text { Amount } \\
\text { added } \\
(\mathrm{mg} / \mathrm{ml})\end{array}$ & Growth & $\begin{array}{c}\text { Erythritol } \\
\text { produced } \\
(\mathrm{mg} / \mathrm{ml})\end{array}$ & $\begin{array}{c}\text { Hexitol } \\
\text { produced } \\
(\mathrm{mg} / \mathrm{ml})\end{array}$ & $\begin{array}{c}\text { Citric acid } \\
\text { produced } \\
(\mathrm{mg} / \mathrm{ml})\end{array}$ \\
\hline Yeast extract & 10 & 0.730 & 68 & 9.4 & 12.9 \\
Meat extract & 30 & 0.950 & 54 & 14.2 & 10.8 \\
Corn steep liquor & 10 & 0.720 & 65 & 9.2 & 12.7 \\
Polypeptone & 30 & 1.000 & 52 & 13.5 & 11.8 \\
Control & 10 & 0.690 & 53 & 8.1 & 13.4 \\
& 30 & 0.900 & 44 & 8.2 & 13.2 \\
\hline
\end{tabular}

Culture conditions: fermentation time $100 \mathrm{hr}, \mathrm{pH} 3.5$ control.

Table III. Effect of Phosphate on Polyol Production by Candida zeylanoides KY 6161, KY 6166, AND Candida lipolytica KY 6143.

Incubation of yeast was carried out as described under the MATERIALS AND METHODS, in which the concentration of $\mathrm{KH}_{2} \mathrm{PO}_{4}$ was replaced by each phosphate source shown in the table.

\begin{tabular}{|c|c|c|c|c|c|c|}
\hline Strain & Phosphate & $\begin{array}{l}\text { Amount } \\
\text { added } \\
(\mathrm{mg} / \mathrm{ml})\end{array}$ & $\begin{array}{l}\text { Growth } \\
\text { (O.D.) }\end{array}$ & $\begin{array}{l}\text { Erythritol } \\
\text { produced } \\
(\mathrm{mg} / \mathrm{ml} \text { ) }\end{array}$ & $\begin{array}{c}\text { Mannitol } \\
\text { produced } \\
(\mathrm{mg} / \mathrm{ml})\end{array}$ & $\begin{array}{c}\text { Citric acid } \\
\text { produced } \\
(\mathrm{mg} / \mathrm{ml})\end{array}$ \\
\hline \multirow[t]{8}{*}{ KY 6166} & $\mathrm{KH}_{2} \mathrm{PO}_{4}$ & 0.3 & 0.580 & 73 & 18 & 12 \\
\hline & & 0.5 & 0.610 & 33 & 23 & 11 \\
\hline & & 1.0 & 0.640 & 2.6 & 63 & 10 \\
\hline & & 2.0 & 0.830 & 0 & 48 & 9 \\
\hline & $\left(\mathrm{NH}_{4}\right)_{2} \mathrm{HPO}_{4}$ & 0.6 & 0.709 & 17 & 34.7 & 14 \\
\hline & & 1.0 & 0.797 & 2.1 & 53.9 & 10 \\
\hline & $\mathrm{Na}_{2} \mathrm{HPO}_{4}$ & 0.5 & 0.620 & 24.5 & 30.9 & 11 \\
\hline & & 1.0 & 0.680 & 1.1 & 57.9 & 8 \\
\hline \multirow[t]{4}{*}{ KY 6161} & $\mathrm{KH}_{2} \mathrm{PO}_{4}$ & 0.3 & 0.580 & 24 & 13 & 14 \\
\hline & & 0.5 & 0.620 & 18 & 20 & 13 \\
\hline & & 1.0 & 0.780 & 0 & 31 & 13 \\
\hline & & 2.0 & 1.000 & 0 & 18 & 12 \\
\hline \multirow[t]{4}{*}{ KY 6143} & $\mathrm{KH}_{2} \mathrm{PO}_{4}$ & 0.3 & 0.520 & 32 & 36 & 10 \\
\hline & & 0.5 & 0.550 & 18 & 42 & 13 \\
\hline & & 1.0 & 0.730 & 0 & 49 & 13 \\
\hline & & 2.0 & 0.910 & 0 & 32 & 15 \\
\hline
\end{tabular}

Culture conditions: fermentation time $100 \mathrm{hr}, \mathrm{pH} 3.5$ control.

that Candida lipolytica produced predominantly $\mathrm{D}$-mannitol in yield of $30 \%$ of $n$-alkane used. In an attempt to clarify the production relationship between mannitol and erythritol, the fermentation with Candida zeylanoides was studied further in larger scale fermentors. It was found that mannitol production began early in the growing phase, and ceased at its stationary phase, while erythritol production occurred differentially with cell growth. Thus, an effective production of mannitol might be expected if the growing phase was kept longer. 
The addition of natural nutrients led to vigorous growth and it resulted in an increase in mannitol production as shown in Table II. On the other hand, it was noticed in preliminary experiments with $300-\mathrm{ml}$ Erlenmeyer flasks that $\mathrm{D}$-mannitol production was significantly varied by phosphate concentration. The effect of phosphate on the mannitol production was examined further. As summarized in Table III, phosphate ion played a significant part in the alternation of polyol production, namely cell growth was stimulated with the higher concentration of phosphate in the medium, but erythritol production was remarkably depressed with such phosphate concentration. This result was a big contrast to the case of polyol production from carbohydrates as reported by Onishi and Suzuki. ${ }^{5}$ A further experiment was performed on the effect of phosphate ion. Time course of fermentation with high concentration of phosphate is shown in Fig. 3. The polyol production was apparently differentiated by the level of phosphate concentration in the culture medium, namely mannitol production occurred at high concen-

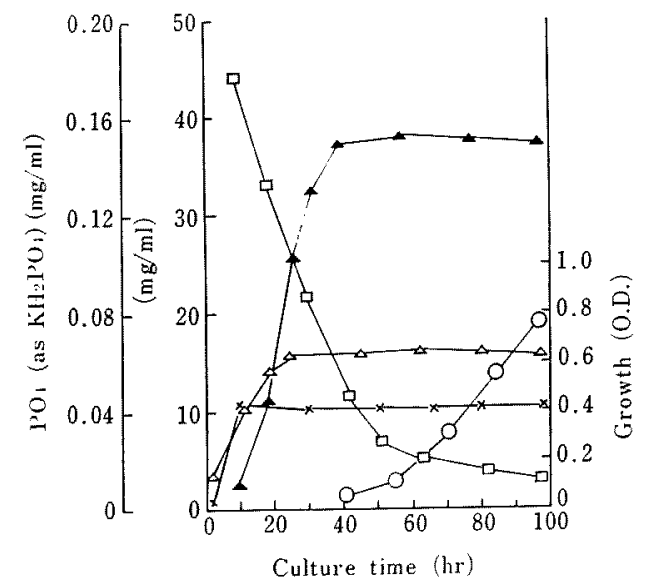

Fig. 3. Time Course of Phosphate in Polyol Production by Candida zeylanoides KY 6166.

Incubation of KY 6166 was carried out with $10 \%$ $(w / v)$ of $n$-alkane in 5 liter fermentor in the medium described under MATERIALS AND METHODS, in which the initial concentration of $\mathrm{KH}_{2} \mathrm{PO}_{4}$ was 0.7 $\mathrm{mg} / \mathrm{ml}$.

$\Delta$, Cell growth; $O$, erythritol; $\Delta$, mannitol; $x$, citiric acid (as free acid); $\square, \mathrm{PO}_{4}$ (as $\mathrm{KH}_{2} \mathrm{PO}_{4}$ ). trations of phosphate and ceased when its concentration was reduced below $0.04 \mathrm{mg} / \mathrm{ml}$ as $\mathrm{KH}_{3} \mathrm{PO}_{4}$, and erythritol production began from this level of phosphate concentration. This result was also ascertained by a feeding experiment of phosphate as shown in Fig. 4.

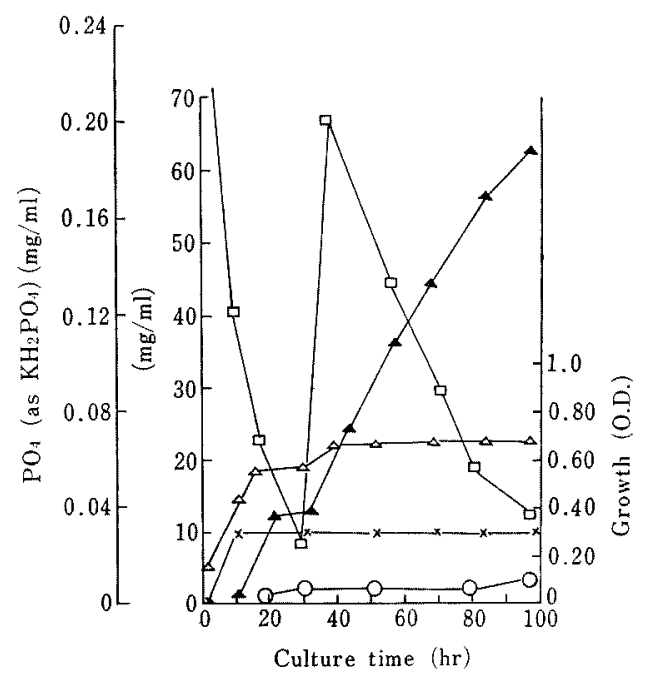

FIG. 4. Effect of Phosphate on Polyol Production by Candida zeylanoides.

Incubation of KY 6166 was carried out with $10 \%$ $(w / v)$ of $n$-alkane in 5 liter fermentor in the medium described under MATERIALS AND METHODS, in which the concentration of $\mathrm{KH}_{2} \mathrm{PO}_{4}$ was replaced as shown in the figure.

$\triangle$, Cell growth; $O$, erythritol; $\Delta$, mannitol; $x$, citric acid (as free acid); $\square, \mathrm{PO}_{4}$ (as $\mathrm{KH}_{2} \mathrm{PO}_{4}$ ).

Mannitol production occurred with vigorous cell growth in the presence of sufficient phosphate and ceased with the reduction of phosphate concentration, but supplementation of phosphate stimulated production again. Thus it is concluded that phosphate functions significantly in the alternation between erythritol and mannitol. Keeping the phosphate concentration at the range from 0.04 to $0.20 \mathrm{mg} / \mathrm{ml}$, as $\mathrm{KH}_{2} \mathrm{PO}_{4}$, the polyol produced was only $\mathrm{D}$-mannitol and the yield was $63 \mathrm{~g} /$ liter, which corresponded to $52 \%$ of $n$-alkane used. Under this condition, the production of citric acid was depressed below $10 \mathrm{~g} /$ liter. From all the above results, it is reasonable to conclude that citric acid fermentation by Candida zeylanoides was converted to erythritol fermentation by lower- 
ing the medium-pH, and was further altered to mannitol fermentation by elevating phosphate concentration and keeping the $\mathrm{pH}$ low.

\section{Other strains capable of producing polyol}

Candida lipolytica KY 6143 and Candida zeylanoides KY 6161, which could produce erythritol and mannitol to some extent in small scale experiments, were compared with the above strain (KY 6166) under the same conditions as described above. As compared to Candida zeylanoides KY 6166 these strains gave a high production ratio of mannitol to erythritol even at low phosphate concentrations as shown in Table III. However, effect of phosphate concentration was also apparent on the alternation ratio between both polyols, namely the polyol produced at high concentration of phosphate was exclusively mannitol.

As has been shown in this paper, mannitol production was achieved in the presence of a high concentration of phosphate using
Candida zeylanoides. It is, however, doubtful whether erythritol production by other strains including Candida lipolytica could be effectively stimulated at a extremely low concentration of phosphate as shown in the case of Candida zeylanoides KY 6166. Therefore, it is plausible that an efficient production of erythritol might depend largely on the ability of the yeast strain.

\section{REFERENCES}

1) K. Hattori and T. Suzuki, Agr. Biol. Chem., 38, 581 (1974).

2) T. Tabuchi and S. Hara, Nippon Nogeikagaku Kaishi, 47, 485 (1973).

3) T. Nakanishi, M. Yamamoto, K. Kimura and K. Tanaka, J. Ferment. Technol., 50, 855 (1972).

4) T. Suzuki, K. Tanaka and S. Kinoshita, Agr. Biol. Chem., 33, 190 (1969).

5) H. Onishi and T. Suzuki, Biotechnol. Bioeng., 12, 913 (1970). 